\title{
33. INTERSTITIAL WATER AND BULK CALCITE CHEMISTRY, LEG 130, AND CALCITE RECRYSTALLIZATION ${ }^{1}$
}

\author{
Margaret L. Delaney² and L.J. Linn ${ }^{2}$
}

\begin{abstract}
We investigated minor element ratios $(\mathrm{Sr} / \mathrm{Ca}$ and $\mathrm{Mg} / \mathrm{Ca}$ ) in bulk sediment samples from Sites $803-807$ using a recently optimized sample treatment protocol for calcium-carbonate-rich sediments consisting of sequential reductive and ion exchange treatments. We evaluated this protocol relative to bulk sediment leaching using samples from Sites 804 and 806 , the two end-member sites in the depth transect, reporting as well $\mathrm{Mn} / \mathrm{Ca}$ and $\mathrm{Fe} / \mathrm{Ca}$ ratios for sediments from these two sites processed by means of both methods. The $\mathrm{Sr} / \mathrm{Ca}$ ratios were only slightly affected by the sample treatment, with an average reduction of $6 \%-7 \%$ caused primarily by the ion exchange step. The reductive sample treatment, designed to be effective at removing Mn-rich oxyhydroxides, has a major effect on $\mathrm{Mg} / \mathrm{Ca}$ ratios, with up to $50 \%$ reduction, whereas little effect occurred in ion exchange alone on $\mathrm{Mg} / \mathrm{Ca}$ ratios. The $\mathrm{Mn} / \mathrm{Ca}$ and $\mathrm{Fe} / \mathrm{Ca}$ ratios were not consistently offset by the sample treatment, and these ratios do not appear to be representative of calcite geochemistry reflecting either ocean history or diagenetic overprinting.

Celestite solubility appears to be an important control on interstitial water $\mathrm{Sr}$ concentrations in these sites, and it must be considered when constructing Sr mass balance models of calcite recrystallization. Calcite $\mathrm{Sr} / \mathrm{Ca}$ ratios (range $\mathrm{I}-2 \mathrm{mmol} / \mathrm{mol}$ ) are similar from site to site when plotted vs. age, with a pattern comparable to that for well-preserved foraminifer tests over the past $40 \mathrm{Ma}$. Interstitial water $\mathrm{Mg}$ and Ca gradients appear to reflect basement character and the intensity of alteration; they can vary substantially over a small area. Calcite $\mathrm{Mg} / \mathrm{Ca}$ ratios (range $1.5-4.5 \mathrm{mmol} / \mathrm{mol}$ ) differ from site to site, with generally higher ratios for sites at a shallower water depth. Increasing calcite $\mathrm{Mg} / \mathrm{Ca}$ ratios correlate with decreasing $\mathrm{Sr} / \mathrm{Ca}$ ratios in the treated samples. No consistent pattern exists for calcite $\mathrm{Mg} / \mathrm{Ca}$ ratios vs. age or depth, nor is any direct correlation to interstitial water $\mathrm{Mg} / \mathrm{Ca}$ ratios present.
\end{abstract}

\section{INTRODUCTION}

Carbonate-rich Sites 803-807 drilled on the Ontong Java Plateau during Ocean Drilling Program (ODP) Leg 130 have similar lithologies dominated by nannofossil ooze and chalk. Calcite geochemistry is interesting at these sites because they encompass a range of water depths with strong gradients in calcite dissolution intensity in a small geographic area. Sedimentation rates for the Neogene vary systematically from site to site, with higher rates for sites at shallower water depths. The interstitial water chemical gradients primarily reflect the dominance of biogenic sediment (both calcite and opal), the paucity of labile organic carbon supply, and the diffusive influence of basalt alteration reactions in the underlying basement (Delaney and Shipboard Scientific Party, 1991). The magnitudes of some interstitial water gradients (e.g., strontium and sulfate) vary primarily with site water depth. These sites, with similar sediment supplies and wellcharacterized site-to-site variations correlated with site water depth, represented an excellent opportunity to apply and evaluate a recently developed sample treatment protocol for determining bulk calcite minor element composition and to interpret the resulting records for their implications about calcite recrystallization.

For studies of minor elements (strontium, magnesium, manganese, sodium, and iron) in basal limestones, Apitz (1991) developed and optimized a bulk calcite pretreatment and selective extraction technique for marine sediments with carbonate contents as low as $50 \%$. This minimizes the effects of phases other than calcite on the measured minor element composition and minimizes the loss of calcite before final dissolution, ensuring representative results. The procedure consists of two sequential steps: (1) a high-pH, room-temperature, reductive cleaning step to remove manganese oxyhydrox-

\footnotetext{
${ }^{1}$ Berger, W.H., Kroenke, L.W., Mayer, L.A., et al., 1993. Proc. ODP, Sci. Results, 130: College Station, TX (Ocean Drilling Program).

${ }^{2}$ Institute of Marine Sciences, University of California, Santa Cruz, Applied Sciences Building, 1156 High Street, Santa Cruz, CA 95064, U.S.A.
}

ides (manganates) that can contain substantial amounts of $\mathrm{Mg}$, and (2) an ion exchange step $(\mathrm{pH}=10.5)$ to remove exchangeable ions and interstitial water salts. Samples are then dissolved in an ammonium acetate-acetic acid buffer, with the solution (which preferentially dissolved calcite) reserved for minor element determinations. Fe-rich oxyhydroxides did not dissolve significantly in any of these steps, nor were they associated with significant $\mathrm{Sr}$ or $\mathrm{Mg}$ relative to that in the calcite fraction (Apitz, 1991).

Numerous studies have investigated minor elements in calcite sediments, especially $\mathrm{Sr}$ and $\mathrm{Mg}$, but the conclusions reached about substantive issues diverge widely. The central issue is the extent to which the records reflect paleocean chemistry (e.g., Renard, 1986), calcite recrystallization (e.g., Baker et al., 1982), or some varying combination of the two with age/depth (e.g., Elderfield et al., 1982). These discussions are complicated by the fact that there is no consensus on the appropriate minor element partition coefficients for predicting the equilibrium $\mathrm{Sr}$ and $\mathrm{Mg}$ composition of inorganically precipitated calcite in marine sediments (Morse and Bender, 1990). Coupled with the debate about the total extent of calcite recrystallization are different interpretations about recrystallization rate variations with depth or age (cf. Richter and DePaolo, 1987, 1988, with Elderfield and Gieskes, 1982; Stout, 1985; Gieskes et al., 1986). It is not known if recrystallization is a one-step process as most studies have assumed, or whether recrystallized calcite itself can further recrystallize (Apitz, 1991). The importance of interstitial water chemical variation through time, especially calcium concentration gradients, in determining the composition of recrystallized calcite has been recognized (Stout, 1985; Delaney, 1989), but quantitative estimates of this effect require making assumptions about past variations that cannot necessarily be verified. The role of minor sedimentary phases in controlling interstitial water chemistry and thus the environment for calcite recrystallization is not well known (e.g., Baker and Bloomer, 1986).

The site characteristics and interstitial water chemistry measurements for the Leg 130 sites that are relevant to interpreting the bulk calcite chemistry are summarized in Table 1 . The Ca concentrations 
Table 1. Site characteristics and interstitial water chemistry summary for Leg 130 sites in order of increasing water depth.

\begin{tabular}{|c|c|c|c|c|c|}
\hline Characteristic & Site 806 & Site 807 & Site 805 & Site 803 & Site 804 \\
\hline Water depth (m) & 2520 & 2805 & 3188 & 3410 & $386 \mathrm{I}$ \\
\hline Latitude $\left({ }^{\circ} \mathrm{N}\right)$ & 0.32 & 3.63 & 1.23 & 2.43 & 1.00 \\
\hline Longitude $\left({ }^{\circ} \mathrm{E}\right)$ & 159.36 & 156.63 & 160.53 & 160.54 & 161.59 \\
\hline \multicolumn{6}{|l|}{ "Relative sediment } \\
\hline${ }^{6} \mathrm{CaCO}_{3}(\%)$ & $90-97$ & $88-96$ & $87-95$ & $83-94$ & $77-94$ \\
\hline \multicolumn{6}{|l|}{ 'Ooze-chalk transition } \\
\hline Depth (mbsf) & 339 & 293 & 288 & 217 & 182 \\
\hline Age (Ma) & $9-10$ & $10-10.5$ & $10.5-11.5$ & 13 & $13.5-14$ \\
\hline \multicolumn{6}{|l|}{ Interstitial $\mathrm{Sr}^{2+}$ plateau } \\
\hline Concentration $(\mu \mathrm{M})$ & 1150 & 900 & 925 & 900 & 600 \\
\hline Depth (mbsf) & 170 & 175 & 130 & 175 & $\geq 200$ \\
\hline Age (Ma) & 5 & $6-7$ & 5 & 8 & $\geq 13$ \\
\hline \multicolumn{6}{|l|}{ Interstitial $\mathrm{SO}_{4}^{2-}$ plateau } \\
\hline Concentration (mM) & 16 & 21.5 & 22 & 23 & 25 \\
\hline \multicolumn{6}{|l|}{${ }^{\text {SStable magnetic polarity }}$} \\
\hline Depth (mbsf) & 16 & 32 & 35 & 49 & 47 \\
\hline Age (Ma) & 0.7 & 2.0 & 1.9 & 4.0 & 4.3 \\
\hline \multicolumn{6}{|l|}{ Interstitial gradients } \\
\hline $\mathrm{Ca}^{2+}(\mathrm{mM} / 100 \mathrm{~m})$ & 2.7 & 1.1 & 4.1 & 6.2 & 3.7 \\
\hline $\mathrm{Mg}^{2+}(\mathrm{mM} / 100 \mathrm{~m})$ & -4.2 & -1.4 & -3.4 & -3.5 & -3.8 \\
\hline$\Delta \mathrm{Ca}^{2+} / \Delta \mathrm{Mg}^{2+}$ & -0.71 & -0.78 & -1.2 & -1.8 & -0.91 \\
\hline \multicolumn{6}{|l|}{${ }^{\mathrm{E}} \mathrm{B}$ asement characteristics } \\
\hline Type of flow & & Massive & & $\begin{array}{l}\text { Successive } \\
\text { pillow lavas }\end{array}$ & \\
\hline Degree of alteration & & $\begin{array}{l}\text { Moderate } \\
\text { or less }\end{array}$ & & $\begin{array}{l}\text { Severe to } \\
\text { moderate }\end{array}$ & \\
\hline Estimated age (Ma) & & 120 & & 90 & \\
\hline Sediment thickness (m) & -1200 & 1380 & -1000 & 630 & $\sim 640$ \\
\hline
\end{tabular}

"The Neogene sediment thickness ratio for each site is relative to the thickness at Site 806 (Berger et al., 1991, table 2).

${ }^{b}$ Ranges of weight percent calcium carbonate for the nanofossil ooze and chalk (Lithologic Unit I) at each site for -2.5 to $25 \mathrm{Ma}$ (Berger et al., 1991, fig. 14). All sites have a lower calcium carbonate percent from 0 to $2.5 \mathrm{Ma}$ : values at the shallowest four sites are $85 \%-90 \%$ in this time range and $7 \%-87 \%$ at the deepest site.

'From Berger et al. (1991, table 5).

${ }^{a}$ From Berger et al. (1991, table 4).

'From Berger et al. (1991). Drilled sediment thickness for Sites 807 and 803, where drilling reached basement. For other sites, sediment thickness was estimated from the acoustic thickness at that site compared to Site 807 (for Sites 806 and 805 ) or to Site 803 (for Site 804).

increase with depth, and $\mathrm{Mg}$ concentrations decrease with depth in the interstitial water at all sites, primarily because of the diffusive influence of basalt alteration reactions in the underlying basement. The $\mathrm{Sr}$ concentrations increase to a plateau at a given depth for each site (Table 1) and are relatively constant deeper in the sediment. Dissolved $\mathrm{Sr} / \mathrm{Ca}$ and $\mathrm{Mg} / \mathrm{Ca}$ profiles for all sites are plotted vs. age in Figure 1; see Delaney and Shipboard Scientific Party (1991) for profiles of individual components (including sulfate) vs. age. The $\mathrm{Sr} / \mathrm{Ca}$ ratios increase with depth to a maximum at each site, with the increase primarily driven by the $\mathrm{Sr}$ increase; they then decrease with increasing depth, primarily because of increasing $\mathrm{Ca}$ concentrations with depth. The $\mathrm{Mg} / \mathrm{Ca}$ ratios decrease with depth at all sites. Sulfate reduction is evident at all sites, apparently limited by the burial of labile carbon and not by the availability of the reductant, with the ratio of plateau concentration relative to seawater sulfate concentration ranging from 0.56 to 0.88 with increasing water depth (Table 1; Delaney and Shipboard Scientific Party, 1991).

We report calcite minor element ratios $(\mathrm{Sr} / \mathrm{Ca}$ and $\mathrm{Mg} / \mathrm{Ca}$ ) for bulk sediment samples from Sites 803-807 using the sample treatment protocol developed by Apitz (1991). We compare the results from this sample treatment method to those from bulk sediment leaches for sediments from the two end-member sites in the Leg 130 depth transect (Sites 806 and 804), reporting as well sediment $\mathrm{Mn} / \mathrm{Ca}$ and $\mathrm{Fe} / \mathrm{Ca}$ ratios for both techniques for these two sites. We interpret $\mathrm{Sr} / \mathrm{Ca}$ and $\mathrm{Mg} / \mathrm{Ca}$ results in terms of their implications for controls on interstitial water and bulk calcite chemistry at these sites and for models of calcite recrystallization.
A

$\mathrm{Sr} / \mathrm{Ca}(\mathrm{mmol} / \mathrm{mol})$
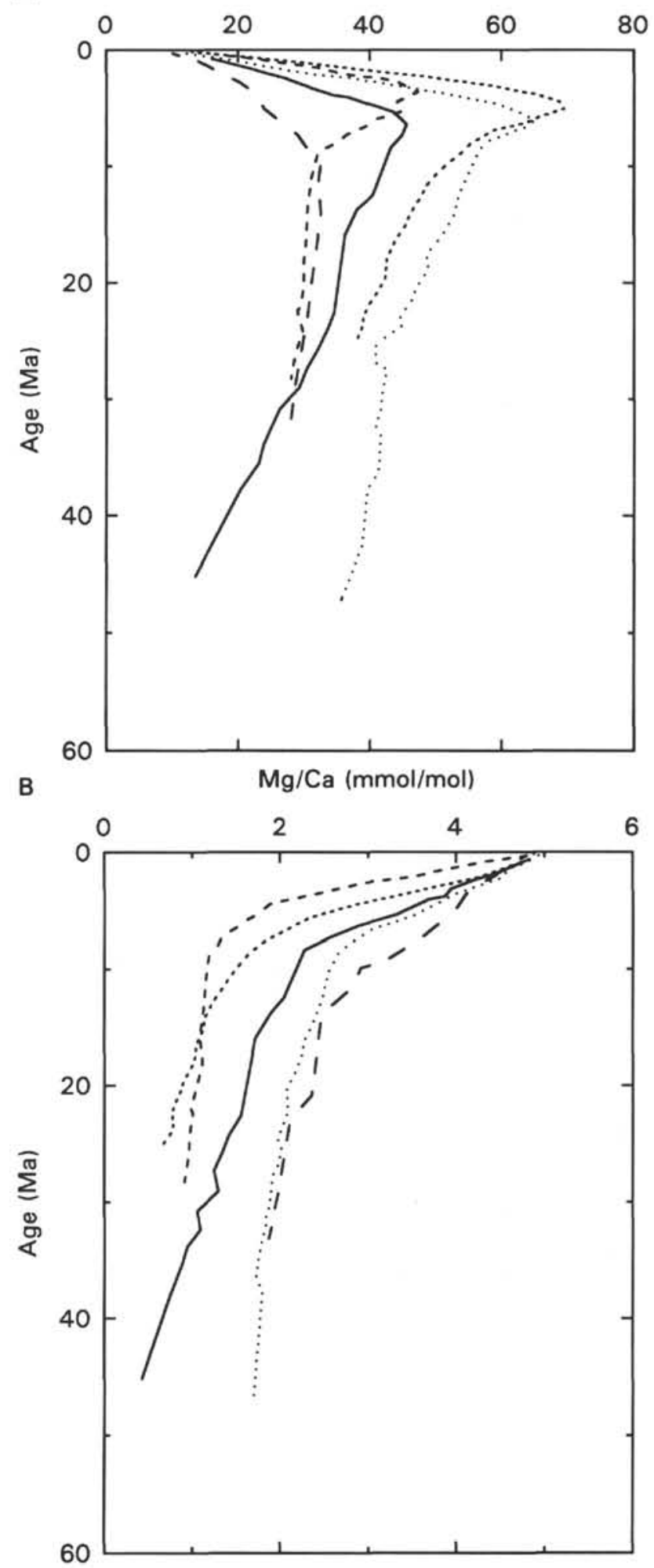

Figure 1. Interstitial water element to Ca ratios vs. age for all sites. $\mathrm{A}$. $\mathrm{Sr} / \mathrm{Ca}$. B. $\mathrm{Mg} / \mathrm{Ca}$. Solid line $=$ Site 803 , long dashed line $=$ Site 804 , medium dashed line $=$ Site 805 , short dashed line $=$ Site 806 , and dotted line $=$ Site 807 . 


\section{MATERIALS AND METHODS}

Bulk sediment samples were taken from the squeeze cakes remaining after shipboard interstitial water extraction. Sample identifiers, depths, and ages (assigned from sample depths based on linear interpolations of ages from age-depth control points given in the respective site chapters) are listed in Appendixes A-E. The majority of samples are from the nannofossil ooze and chalk constituting Lithologic Unit I at all sites; thus, they are representative of the carbonate-rich character and progressive physical alteration with age at these sites. The two deepest samples at Site 807 are from the limestones/siliceous limestones of Lithologic Unit II at that site. The deepest sample at Site 803 is from the basal siliciclastic sediments of Lithologic Unit III, with $\mathrm{CaCO}_{3}<1 \%$; these results are not representative of calcite composition and, although given in the table for that site, are excluded from the figures and this discussion.

We used the method developed by Apitz (1991) with slight modifications. We used smaller sample aliquots ( $20 \mathrm{mg}$ rather than $75 \mathrm{mg}$ ), with correspondingly smaller solution volumes and centrifugation and pipette transfer of solutions to eliminate solution decantation and filtering. Briefly, samples were gently ground, weighed, and transferred to acid-cleaned centrifuge tubes. Many samples were run in duplicate. To each sample, $10 \mathrm{~mL}$ of reducing solution $\left(25 \mathrm{~g} \mathrm{NH}_{2} \mathrm{OH}\right.$. $\mathrm{HCl}$ diluted with $200 \mathrm{~mL}$ concentrated $\mathrm{NH}_{4} \mathrm{OH}$ and $300 \mathrm{~mL}$ distilled water) were added. Samples were shaken at room temperature (6-12 hr) and then centrifuged. After the solutions were removed and discarded, this step was repeated. Samples were shaken with $10 \mathrm{~mL}$ $1 \mathrm{M} \mathrm{NH}_{4} \mathrm{OH}$ for $1 \mathrm{hr}$ and were then centrifuged; again, the solutions were removed and discarded. A small number of samples from Site 806 were also treated with only this second, ion exchange step. Samples were dissolved for $5 \mathrm{hr}$ in $10 \mathrm{~mL} 0.1 \mathrm{M}$ ammonium acetateacetic acid buffer, with hourly shaking and venting. Samples were again centrifuged, and the solutions reserved for analyses. To compare the current method with bulk leaching used in previous studies, sample splits from Sites 804 and 806 were dissolved according to the preceding steps with no sample pretreatment. Samples treated with the full protocol will be designated as "treated" in the following, whereas those that were simply dissolved will be referred to as "bulk leach" samples.

Known volumes of the reserved solutions were acidified to $0.1 \mathrm{~N}$ final acid concentration with small volumes of clean concentrated $\mathrm{HCl}$ or $\mathrm{HNO}_{3} . \mathrm{Ca}, \mathrm{Sr}$, and $\mathrm{Mg}$ were determined at the recommended conditions by flame atomic absorption spectrophotometry (FAAS) using the solutions acidified with $\mathrm{HCl}$ after being appropriately diluted with lanthanum as an ionization suppressant. For FAAS, we used a Perkin-Elmer Model 2380 spectrophotometer with an airacetylene flame and a single-slot burner head. $\mathrm{Mn}$ and Fe were determined by graphite furnace atomic absorption spectrophotometry (GFAAS) at the recommended conditions on dilutions of the aliquots acidified with $\mathrm{HNO}_{3}$. For GFAAS, we used a Perkin-Elmer Model 5000 spectrophotometer with a continuum source background correction, a Perkin-Elmer heated-graphite-analyzer (Model 500), and a Perkin-Elmer AS-1 autosampler.

Reagent and instrumental blanks were consistently minor compared to solution concentrations of analyte elements. Within a given analytical run, relative errors of concentration determinations for solution replicates were generally less than $\pm 2 \%$ (1s standard deviation/mean). For $\mathrm{Sr} / \mathrm{Ca}$ and $\mathrm{Mg} / \mathrm{Ca}$ ratios, replicate analyses over a number of analytical runs of a set of four solutions with compositions similar to those of our samples had 1 s standard deviations relative to their means equivalent to $\pm 3 \%-5 \%$ for the $\mathrm{Sr} / \mathrm{Ca}$ ratios and $\pm 4 \%-6 \%$ for the $\mathrm{Mg} / \mathrm{Ca}$ ratios. This set of solutions had known additions of minor elements; the mean measured differences between pairs of these solutions for $\mathrm{Sr}$ and $\mathrm{Mg}$ concentrations agreed with the expected differences within analytical error $(<2 \%)$, indicating the accuracy of the determinations. Relative errors of the means for the solid replicates for $\mathrm{Sr} / \mathrm{Ca}$ ratios were typically $\pm 0.1 \%-5 \%$, ranging up to $16 \%$; for the $\mathrm{Mg} / \mathrm{Ca}$ ratios, relative errors of the means were $\pm 0.1 \%-10 \%$, ranging up to $25 \%$. Relative errors for solid replicates for $\mathrm{Mn} / \mathrm{Ca}$ and $\mathrm{Fe} / \mathrm{Ca}$ ratios were $\pm 1 \%-20 \%$, indicating the more heterogeneous sediment distributions of these elements relative to $\mathrm{Ca}$.

\section{RESULTS}

Minor element ratios for sediment samples for all sites are given in Appendixes A-E, with results reported as molar ratios to $\mathrm{Ca}$ (units of $\mathrm{mmol} / \mathrm{mol}$ ) for each element. In the following, we first compare the results of the sample treatment methods, then present the profiles of minor element ratios.

For the sediment samples from Sites 804 and $806, \mathrm{Sr} / \mathrm{Ca}$ ratios are similar regardless of sample treatment, with the $\mathrm{Sr} / \mathrm{Ca}$ ratios in the treated samples averaging $6 \%-7 \%$ lower than those in the untreated replicates, regardless of the site (Appendixes B and D; Fig. 2A). The $\mathrm{Sr} / \mathrm{Ca}$ ratios for sample replicates from Site 806 treated with only the ion exchange step are similar to those receiving the full treatment, indicating that in most cases this $\mathrm{Sr} / \mathrm{Ca}$ reduction is a result of the ion exchange step. This may represent small amounts of residual interstitial water and/or exchangeable ions with a higher $\mathrm{Sr} / \mathrm{Ca}$ ratio than the bulk calcite, thus accounting for the small reduction in the $\mathrm{Sr} / \mathrm{Ca}$ ratios. Two samples from Site 804 with unusually high $\mathrm{Sr} / \mathrm{Ca}$ ratios in the untreated samples have much greater reductions than average; one of these also has large reductions in the $\mathrm{Mn} / \mathrm{Ca}$ and $\mathrm{Fe} / \mathrm{Ca}$ ratios with treatment; these adjacent samples both have relatively high $\mathrm{Fe} / \mathrm{Ca}$ ratios (Appendix B).

For the $\mathrm{Mg} / \mathrm{Ca}$ ratios, by contrast, the two sample treatment protocols resulted in quite different minor element ratios, indicating the importance of multiple sources of $\mathrm{Mg}$ even in these two highcarbonate sites and despite the association of the majority of the $\mathrm{Mg}$ with calcite (Appendix B and D; Fig. 2B). The reduction in the $\mathrm{Mg} / \mathrm{Ca}$ ratios averages $50 \%$ for samples from Site 804 , with a lower average carbonate content (Table 1) and generally lower $\mathrm{Mg} / \mathrm{Ca}$ ratios both before and after treatment. The reduction in $\mathrm{Mg} / \mathrm{Ca}$ ratios for samples from Site 806 is somewhat smaller, averaging $30 \%$ overall, although the offset in $\mathrm{Mg} / \mathrm{Ca}$ ratios produced by the two sample treatment methods decreases with increasing depth in the sediment, from $50 \%$ in the shallowest samples to $20 \%$ in the deeper ones. The $\mathrm{Mg} / \mathrm{Ca}$ ratios produced by the ion exchange treatment alone did not differ greatly from the ratios resulting from bulk sediment leaching for samples from Site 806, indicating the importance of the reductive cleaning step in determining $\mathrm{Mg} / \mathrm{Ca}$ ratios that reflect the calcite fraction alone.

The $\mathrm{Mn} / \mathrm{Ca}$ ratios, by contrast, were not consistently affected either by the full sample treatment or by the ion exchange step alone for most samples (Appendix B and D; Fig. 2C). A few samples at Site 804 , representing the shallowest samples and those with high $\mathrm{Fe} / \mathrm{Ca}$ samples near $10 \mathrm{Ma}$, have high $\mathrm{Mn} / \mathrm{Ca}$ ratios from bulk sediment leaching that are substantially reduced with sample treatment. The lack of effect may reflect the generally reducing nature of these sediments, with any easily reducible manganates removed early on (before the onset of sulfate reduction that occurs in all sites) and thus not available to chemical reduction in the lab.

The $\mathrm{Fe} / \mathrm{Ca}$ ratios, not expected to be affected by the roomtemperature reductive treatment, also showed no consistent offset with either sample treatment, with an average reduction for treated samples of 5\% (Fig. 2D). One sample at Site 804 had a large reduction in $\mathrm{Fe} / \mathrm{Ca}$ ratio with treatment; this is the same sample showing unusually large reductions in $\mathrm{Sr} / \mathrm{Ca}$ and $\mathrm{Mn} / \mathrm{Ca}$ ratios.

Stable magnetic polarity signals are lost at a consistent depth at each site (Table 1). This depth increases with increasing site water depth and corresponds to the start of sulfate reduction; it presumably reflects the dissolution/reduction of iron oxides, including magnetite, during organic matter oxidation. No clear signature is present in the $\mathrm{Mn} / \mathrm{Ca}$ or $\mathrm{Fe} / \mathrm{Ca}$ ratios vs. age or depth coincident with these 
A

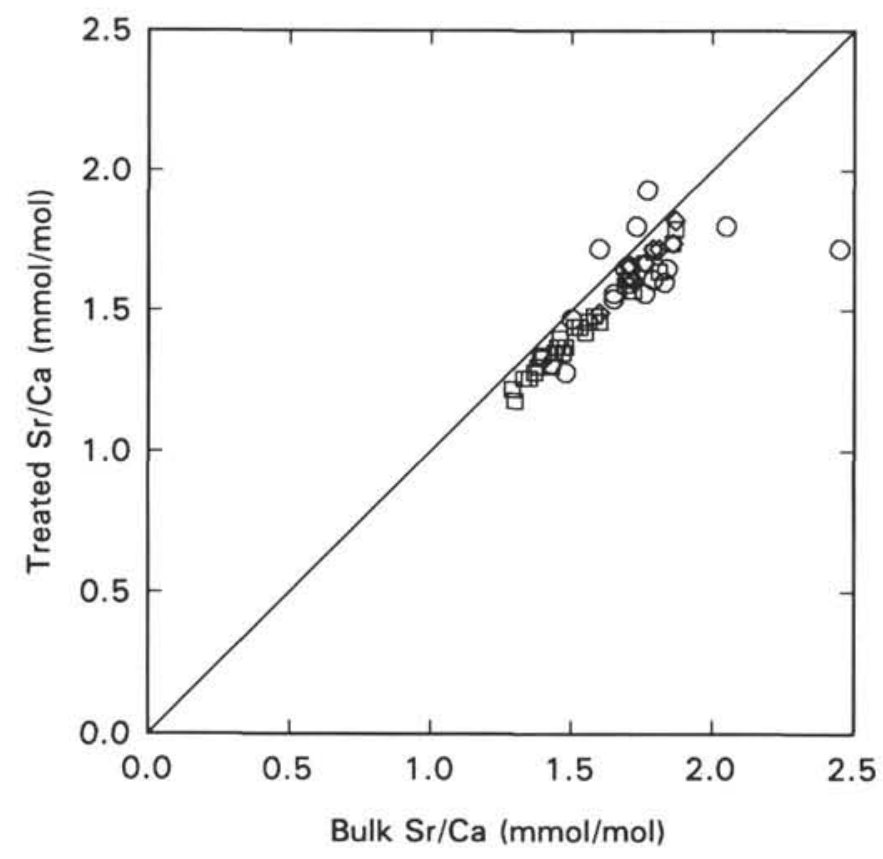

C

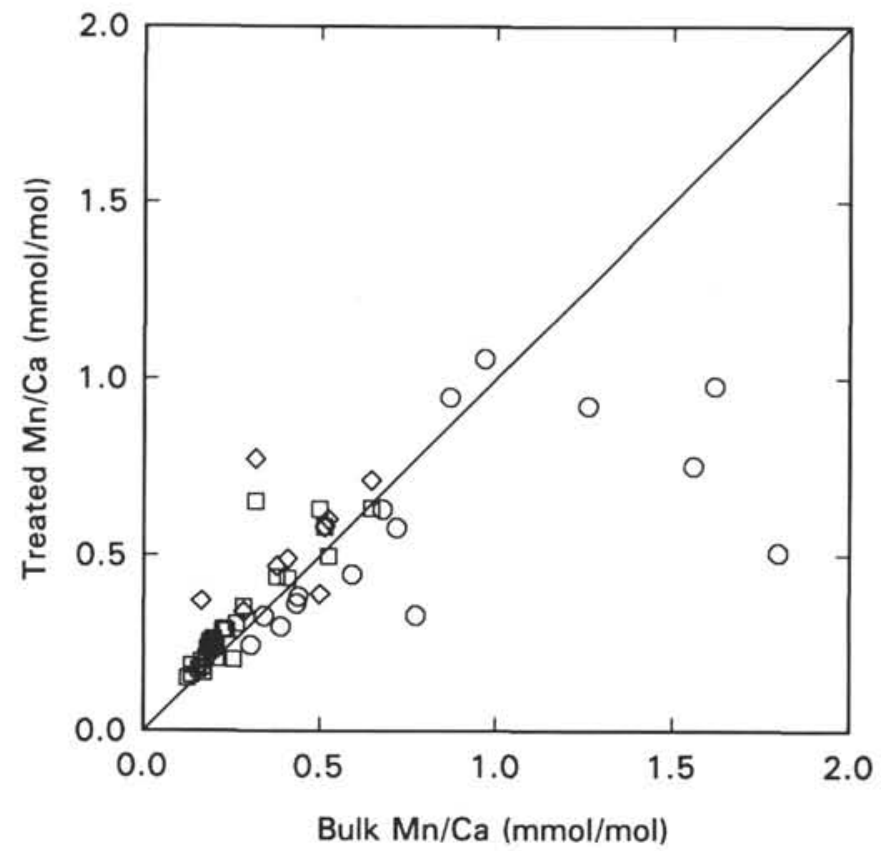

B

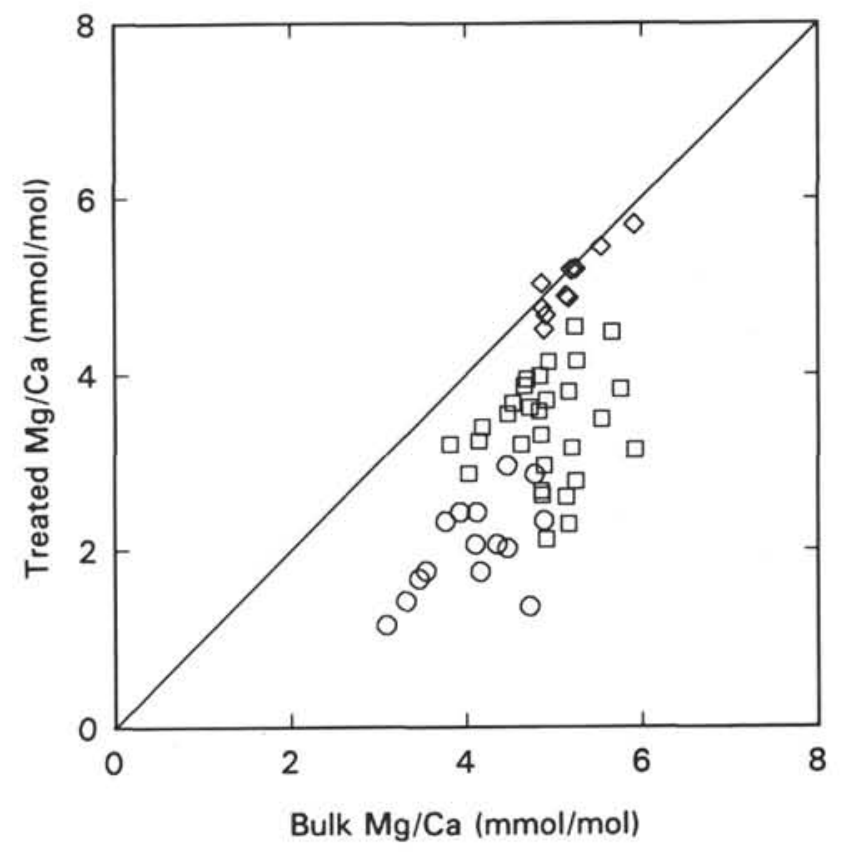

D

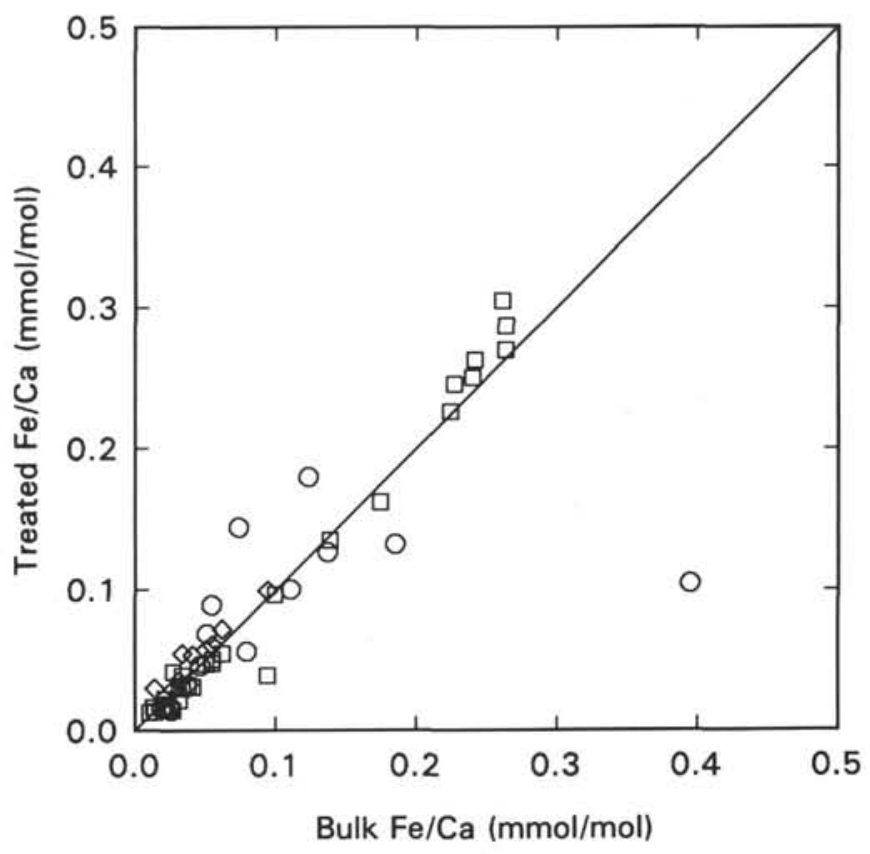

Figure 2. Minor element to Ca ratios in treated vs. bulk leach sediment samples. A. $\mathrm{Sr} / \mathrm{Ca} . \mathrm{B} . \mathrm{Mg} / \mathrm{Ca} . \mathrm{C}$. $\mathrm{Mn} / \mathrm{Ca} . \mathrm{D}$. Fe/Ca. $\mathrm{Circles}=\mathrm{Site} 804$, squares $=\mathrm{Site} 806$ full treatment, and diamonds $=$ Site 806 ion exchange step only.

transitions (results from treated samples are plotted vs. age in Fig. 3). For Site $804, \mathrm{Mn} / \mathrm{Ca}$ ratios are generally $0.2-1.0 \mathrm{mmol} / \mathrm{mol}$ (Fig. $3 \mathrm{~A}$ ). The $\mathrm{Fe} / \mathrm{Ca}$ ratios are variable from $12 \mathrm{Ma}$ to the present, ranging from 0.05 to $0.20 \mathrm{mmol} / \mathrm{mol}$, and are then consistently low from 12 to $35 \mathrm{Ma}(<0.05 \mathrm{mmol} / \mathrm{mol}$; Fig. $3 \mathrm{~B})$. The $\mathrm{Mn} / \mathrm{Ca}$ ratios are always lower at Site 806 than at Site 804 in equivalent age samples, and they generally increase from $4 \mathrm{Ma}$ to the present (from 0.2 to $0.7 \mathrm{mmol} / \mathrm{mol}$ ), with consistently low values of $0.2-0.3 \mathrm{mmol} / \mathrm{mol}$ from 4 to $25 \mathrm{Ma}$ (Fig. 3A). The Fe/Ca ratios at Site 806 are generally less than $0.05 \mathrm{mmol} / \mathrm{mol}$ from $13 \mathrm{Ma}$ to the present and are 0.15 $0.30 \mathrm{mmol} / \mathrm{mol}$ from 14 to $25 \mathrm{Ma}$ (Fig. 3B). Given this variability, it is difficult to interpret these patterns as reflecting calcite geochemistry at these sites, either original or as overprinted by recrystallization.

$\mathrm{The} \mathrm{Sr} / \mathrm{Ca}$ ratios from treated samples are plotted vs. depth and age for all sites in Figure 4. The $\mathrm{Sr} / \mathrm{Ca}$ ratios generally fall between 1.1 and $1.9 \mathrm{mmol} / \mathrm{mol}$, with only the deepest sample at Site 807 having a lower ratio. When the $\mathrm{Sr} / \mathrm{Ca}$ ratios are plotted vs. age rather than depth, a smaller range of values is present in any given interval. The 
A

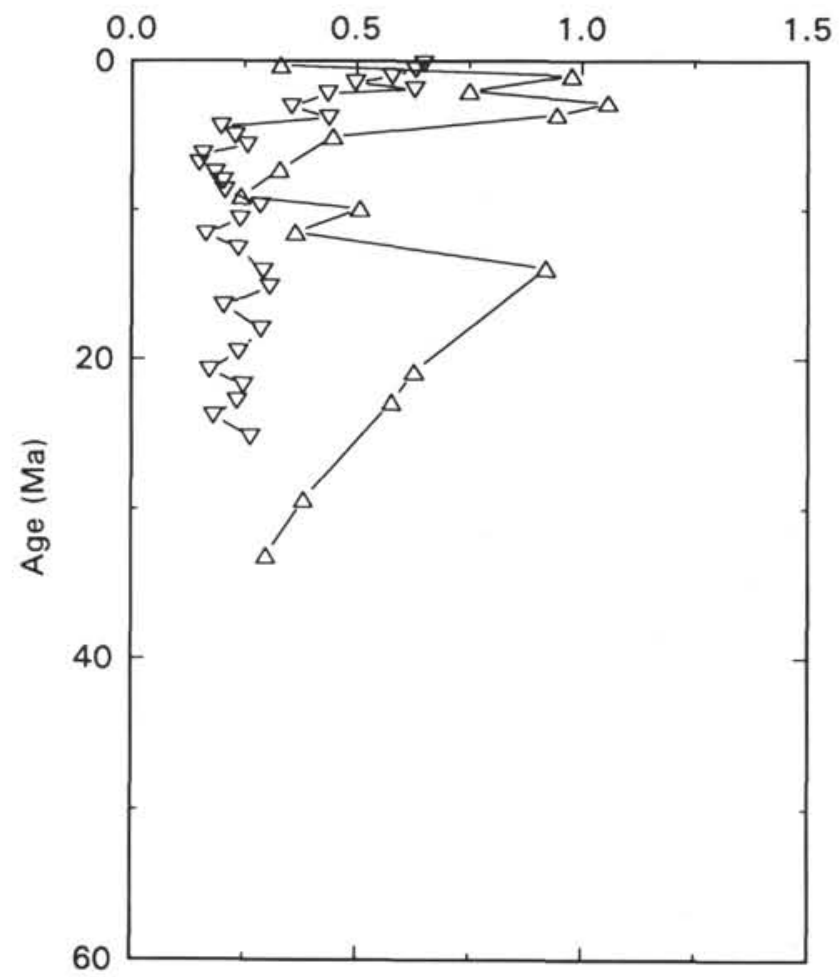

B

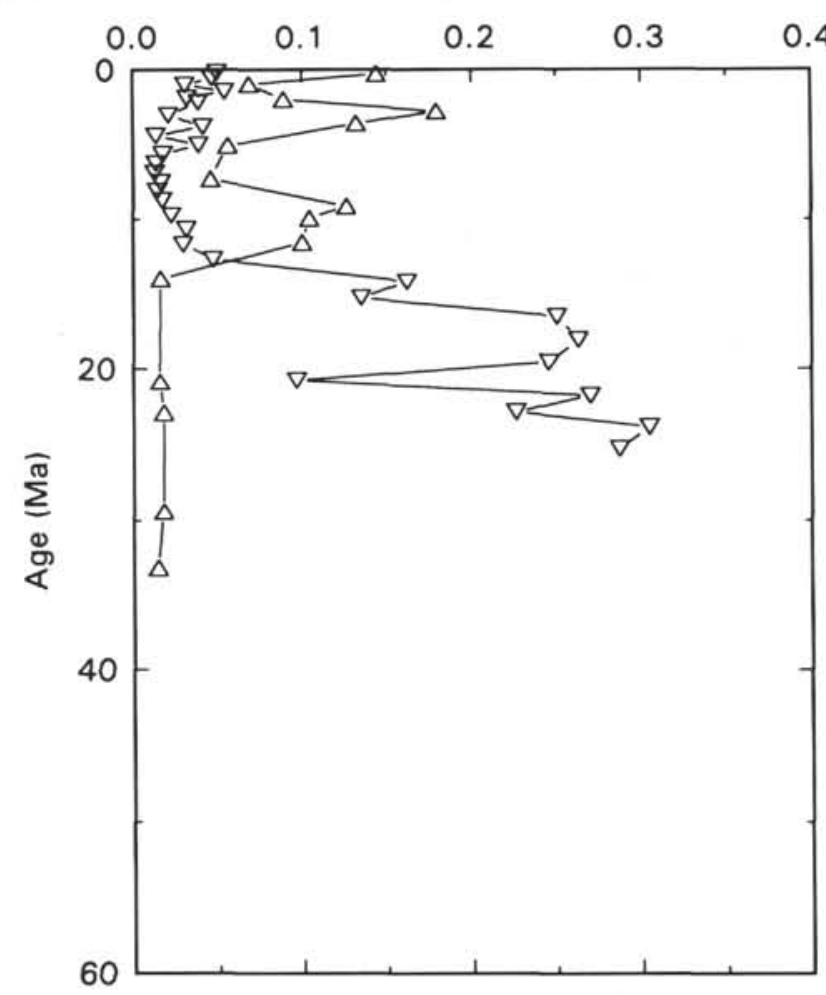

Figure 3. $\mathrm{Mn} / \mathrm{Ca}(\mathbf{A})$ and $\mathrm{Fe} / \mathrm{Ca}(\mathbf{B})$ ratios (treated samples) vs. age. Triangles $=$ Site 804 , and inverted triangles $=$ Site 806 .
A

$\mathrm{Sr} / \mathrm{Ca}(\mathrm{mmol} / \mathrm{mol})$
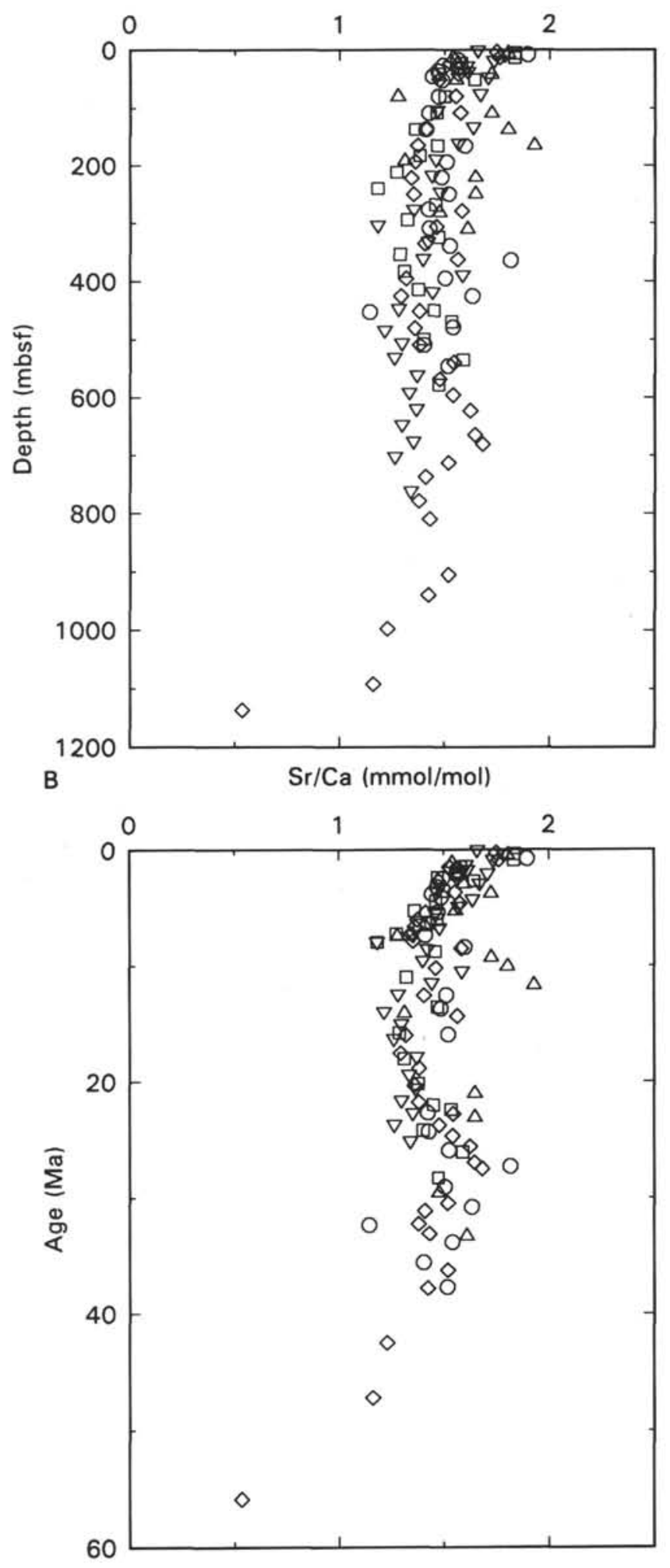

Figure 4. Sr/Ca ratios (treated samples) vs. depth (A) and age (B) for all sites. Circles $=$ Site 803 , triangles $=$ Site 804 , squares $=$ Site 805 , inverted triangles $=$ Site 806, and diamonds $=$ Site 807. 
A

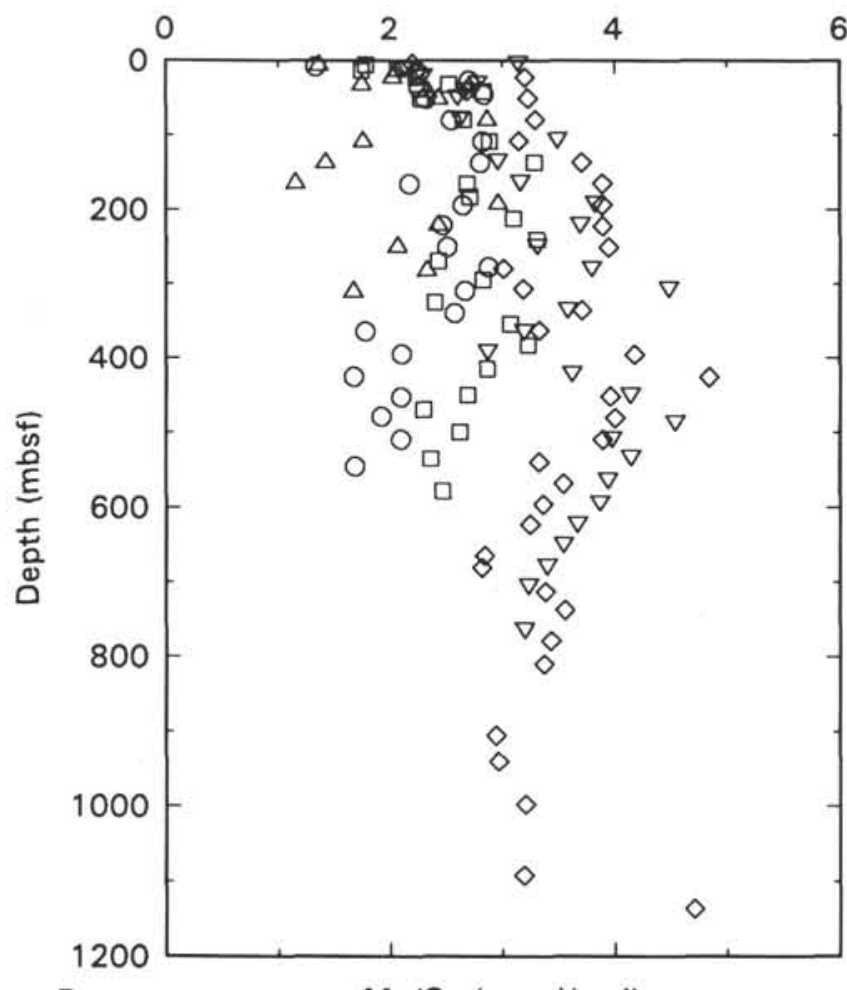

B

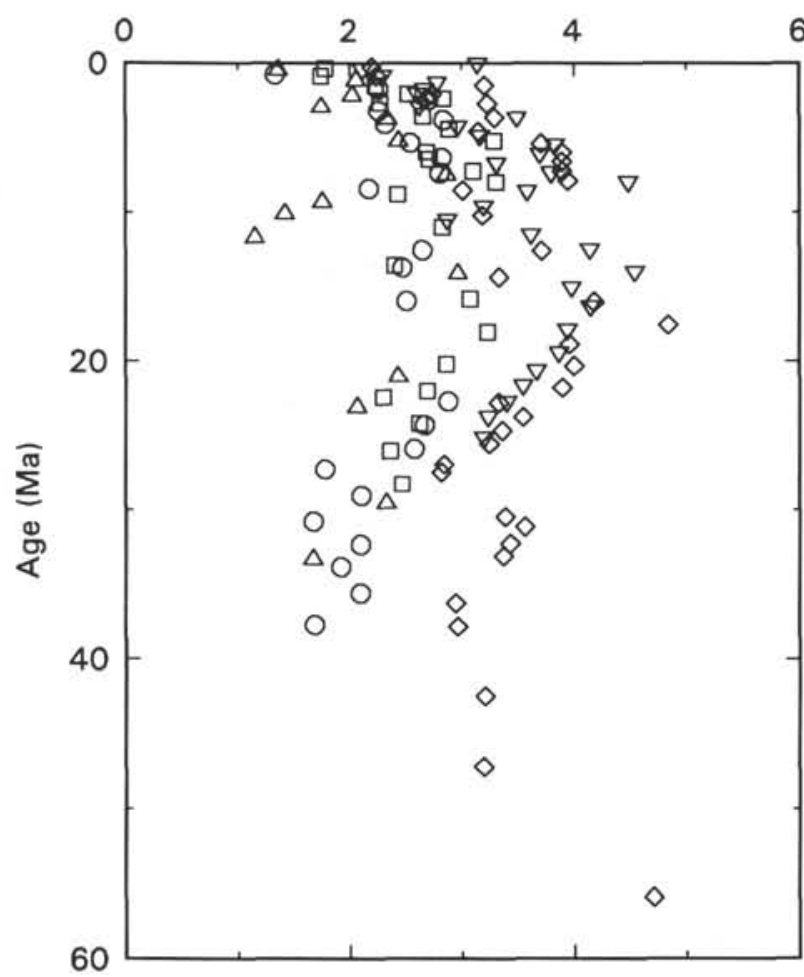

Figure 5. Mg/Ca ratios (treated samples) vs. depth (A) and age (B) for all sites. Symbols for each site are as in Figure 4.
$\mathrm{Mg} / \mathrm{Ca}$ ratios from the treated samples are plotted vs. depth and age in Figure 5. The $\mathrm{Mg} / \mathrm{Ca}$ ratios range between 1.5 and $4.5 \mathrm{mmol} / \mathrm{mol}$, with little agreement in the patterns from individual sites with either depth or age.

\section{DISCUSSION}

\section{Sample Treatment Protocols and Calcite Minor Element Ratios}

A comparison of sample treatment methods for sediment samples from Sites 804 and 806 demonstrated significant effects on $\mathrm{Mg} / \mathrm{Ca}$ ratios (Fig. 2B), despite the dominance of calcite in the sediments and the association of the bulk of $\mathrm{Mg}$ with the calcite fraction, as previously observed (Apitz, 1991). The reduction in $\mathrm{Mg} / \mathrm{Ca}$ ratios, presumably from the removal of $\mathrm{Mg}$ not associated with calcite, was caused primarily by the reductive treatment despite the lack of consistent offset in the $\mathrm{Mn} / \mathrm{Ca}$ ratios (Fig. 2C); lower carbonate sediments, with lower $\mathrm{Mg} / \mathrm{Ca}$ ratios, had larger reductions in $\mathrm{Mg} / \mathrm{Ca}$ ratios relative to the bulk leach values. These observations, along with the lack of correlation between the $\mathrm{Mg} / \mathrm{Ca}$ and $\mathrm{Mn} / \mathrm{Ca}$ ratios, suggest that easily soluble silicates must contribute $\mathrm{Mg}$, with little or no $\mathrm{Ca}$, to bulk leach $\mathrm{Mg} / \mathrm{Ca}$ ratios (Apitz, 1991). The reductive treatments apparently remove this $\mathrm{Mg}$, leading to the greater decrease in $\mathrm{Mg} / \mathrm{Ca}$ ratios after treatment for the less carbonate-rich site. The $\mathrm{Mg} / \mathrm{Ca}$ ratios in the calcite sediments from different studies using various sample treatment protocols are therefore difficult to interpret as consistently reflecting calcite chemical composition. In contrast, sample treatment had little effect on $\mathrm{Sr} / \mathrm{Ca}$ ratios compared to bulk leaching with no pretreatment, with the small reductions that did occur caused by the high-pH ion exchange step (Fig. 2A). The $\mathrm{Sr} / \mathrm{Ca}$ ratios measured from the bulk sediment samples, therefore, can be interpreted with some confidence as reflecting calcite chemical composition.

The $\mathrm{Mn} / \mathrm{Ca}$ and $\mathrm{Fe} / \mathrm{Ca}$ ratios were not consistently affected by sample treatment (Figs. 2C and 2D). Lattice-bound $\mathrm{Mn} / \mathrm{Ca}$ and $\mathrm{Fe} / \mathrm{Ca}$ ratios in planktonic foraminifer tests have upper limits of 0.01 and $0.002 \mathrm{mmol} / \mathrm{mol}$, respectively (Boyle, 1981). The $\mathrm{Mn} / \mathrm{Ca}$ ratios in the foraminifer tests from sediment cores can be substantially higher as a result of the overgrowths of Mn-rich carbonate in reducing sediments; for example, values up to $0.7 \mathrm{mmol} / \mathrm{mol}$ have been observed in Panama Basin sediments (Boyle, 1983). Lattice-bound $\mathrm{Mn} / \mathrm{Ca}$ and $\mathrm{Fe} / \mathrm{Ca}$ ratios for nannofossil calcite are not known but are also expected to be low because of the low concentrations of dissolved Mn and $\mathrm{Fe}$ in oceanic surface waters. The $\mathrm{Mn} / \mathrm{Ca}$ ratios measured in these bulk sediment samples are 15-100 times the expected ratio for lattice-bound $\mathrm{Mn} / \mathrm{Ca}$, but this may reflect the presence of $\mathrm{Mn}$-rich carbonate overgrowths that should be visible with cathodoluminescence (e.g., Apitz, 1991). The Mn/Ca ratios are higher at Site 804 at a greater water depth with slower sedimentation rate and lower total sulfate reduction. Temporal and spatial $\mathrm{Mn} / \mathrm{Ca}$ variability may result from a combination of variability in the supply of $\mathrm{Mn}$ oxides and the reduction intensity. The $\mathrm{Fe} / \mathrm{Ca}$ ratios are 5-100 times the ratios expected for lattice-bound $\mathrm{Fe} / \mathrm{Ca}$; these may be elevated because of the solubility of $\mathrm{Fe}$ oxides in the acetate buffer used for dissolution in all treatments here (Boyle, 1981). The $\mathrm{Mn} / \mathrm{Ca}$ and $\mathrm{Fe} / \mathrm{Ca}$ ratios do not appear to represent the paleoceanographic environment at these sites, nor do they represent calcite diagenetic history in any straightforward fashion.

\section{$\mathrm{Sr} / \mathrm{Ca}$ Ratios in Interstitial Water and Bulk Calcite}

The $\mathrm{Sr}$ concentrations in interstitial water increase with depth at all sites, reaching plateau values, and then are fairly constant with increasing depth (Delaney and Shipboard Scientific Party, 1991). The relatively constant depth for the $\mathrm{Sr}$ maximum at these sites (Table 1) indicates that controls other than diffusional path length relative to sedimentation rate (Gieskes and Johnson, 1984) are important in 
determining the position of the maxima. The position of the $\mathrm{Sr}$ maximum, shallower and younger than the ooze/chalk boundary, indicates the importance of calcite diagenesis producing dissolved $\mathrm{Sr}$ above this boundary.

Interstitial water $\mathrm{Sr}$ plateau concentrations decrease with increasing site water depth and are generally inversely related to sulfate plateau concentrations, with higher sulfate concentrations corresponding to lower $\mathrm{Sr}$ concentrations (Table 1 ). This is strongly suggestive that interstitial $\mathrm{Sr}$ concentrations are limited by equilibrium with solid $\mathrm{SrSO}_{4}$ (i.e., celestite). Discrete celestite nodules were observed in the dominant nannofossil ooze and chalk lithologies in sites from the Lord Howe Rise (Deep Sea Drilling Project [DSDP] Leg 90) and in a mid-Pacific site (DSDP Site 315) (Baker and Bloomer, 1986). Interstitial water profiles of $\mathrm{Sr}$ and sulfate at those sites are similar to those from the Leg 130 sites. Interpolating celestite solubility products (which increase with increasing pressure) and solution activity coefficients for the water depths of the Leg 130 sites results in saturation states close to 1 , with Site 804 perhaps slightly undersaturated.

Several important implications from this result can be made. Even in these low organic carbon sediments, the amount of labile organic carbon controls the extent of sulfate reduction, and the extent of sulfate reduction, by equilibrium with celestite, limits interstitial $\mathrm{Sr}$ increases. Celestite, not observed as discrete nodules in these sites and potentially difficult to identify and quantify as a disseminated phase, is significant in controlling interstitial water composition. This complicates the "hindcasting" of $\mathrm{Sr}$ profiles for time-averaging interstitial water composition in calcite recrystallization computations (Delaney, 1989). In addition, mass balance recrystallization models of $\mathrm{Sr}$ and $\mathrm{Sr}$ isotopes are incomplete if they consider only a closed system of recrystallizing calcite and interstitial water with diffusional loss of $\mathrm{Sr}$, because there is an additional $\mathrm{Sr}$ sink in the sediments.

The $\mathrm{Sr} / \mathrm{Ca}$ ratios in bulk calcite from the various sites agree reasonably well when plotted vs. age (Fig. 4B). This pattern could reflect paleoceanic chemical variations, the effects of calcite recrystallization, or some combination of the two. If calcite recrystallization in equilibrium with present-day interstitial water were the dominant control, calcite $\mathrm{Sr} / \mathrm{Ca}$ ratios should reflect the same site-to-site ordering as interstitial $\mathrm{Sr} / \mathrm{Ca}$ ratios (Fig. 1A). This does not appear to be the case. Using an effective partition coefficient for $\mathrm{Sr}$ of $0.035 \times 10^{-3}$ (Baker et al., 1982; Delaney, 1989; Apitz, 1991), interstitial water $\mathrm{Sr} / \mathrm{Ca}$ ratios would translate into bulk calcite ratios of $0.7-2.5$ $\mathrm{mmol} / \mathrm{mol}$. Observed ratios at these sites are higher, coincide, or are lower than predicted inorganic calcite ratios, depending on site and age range. Previous observations diagnosing complete calcite recrystallization from the agreement of $\mathrm{Sr} / \mathrm{Ca}$ values in bulk calcite with those predicted for inorganic calcite in equilibrium with present interstitial water (Baker et al., 1982; Elderfield et al., 1982) may instead reflect fortuitous agreement of the two values. The effect of averaging interstitial water composition over time (Delaney, 1989) is to reduce the predicted inorganic calcite "equilibrium" $\mathrm{Sr} / \mathrm{Ca}$ ratios in the range of the $\mathrm{Sr} / \mathrm{Ca}$ maximum and to increase them deeper in the sediment. A factor of 2 spread in predicted values not reflected in the measured calcite composition still occurs in generally the same order as the present profiles. These sediments are too young for the effects of substantial overprinting of early recrystallization to have significant influence on $\mathrm{Sr} / \mathrm{Ca}$ ratios (Apitz, 1991).

The pattern of $\mathrm{Sr} / \mathrm{Ca}$ ratios with age over the past $40 \mathrm{Ma}$ is generally comparable to that observed in well-preserved foraminifer tests (Graham et al., 1982). The foraminifer pattern has minima at about 8-9 and $50 \mathrm{Ma}$, and a long-term increase of about $10 \%$ in $\mathrm{Sr} / \mathrm{Ca}$ ratios from $65 \mathrm{Ma}$ to the present. The minimum at 8-9 Ma is apparent in this pattern (Fig. 4B), as are relatively constant values from 40 to $10 \mathrm{Ma}$. Absolute $\mathrm{Sr} / \mathrm{Ca}$ ratios in this study are higher especially in the youngest sediments, but this may be a result of the higher $\mathrm{Sr} / \mathrm{Ca}$ ratios in nannofossil calcite and thus bulk calcite relative to foraminifer tests (Baker et al., 1982; Stout, 1985). Although age-controlled recrystal- lization may play a part, the controls on these bulk calcite $\mathrm{Sr} / \mathrm{Ca}$ records may be dominantly seawater chemistry.

\section{$\mathbf{M g} / \mathrm{Ca}$ Ratios in Interstitial Water and Bulk Calcite}

Interstitial water $\mathrm{Ca}$ and $\mathrm{Mg}$ gradients differ from site to site (Table 1) despite the small geographic area and the general similarity expected in basement characteristics. The ratio of the $\mathrm{Ca}$ gradient to the $\mathrm{Mg}$ gradient ranges from -0.7 to -1.8 , comparable to the average of -1.5 observed for sites on basaltic basement (McDuff, 1981). No simple pattern is present for the magnitude of gradients by site location, water depth, or total sediment thickness. However, basement drilling at two of these sites (Sites 807 and 803 ) revealed quite different characteristics in terms of the character of the flows, the degree of alteration, and basement age (Table 1). Observed interstitial water gradients at these two sites are consistent with these observations. Site 803 , with severe to moderate alteration of successive pillow lavas, has larger $\mathrm{Ca}$ and $\mathrm{Mg}$ gradients than does Site 807 , which has massive flows and only moderate or less alteration. This confirms that local and perhaps temporal variability in basalt basement alteration reactions responsible for $\mathrm{Ca}$ and $\mathrm{Mg}$ interstitial water gradients does occur (McDuff, 1981). This variability makes hindcasting of the development of $\mathrm{Ca}$ and $\mathrm{Mg}$ gradients for calcite recrystallization models (Delaney, 1989) for a given site or region inherently uncertain.

The $\mathrm{Mg} / \mathrm{Ca}$ ratios in treated bulk sediment samples, although presumably reflecting bulk calcite composition, do not agree well from site to site either vs. depth or age (Fig. 5). The values are comparable to $\mathrm{Mg} / \mathrm{Ca}$ ratios measured in two other Ontong Java Plateau sites: Sites $288(3000 \mathrm{~m})$ and $289(2224 \mathrm{~m})$, where studies also showed no consistent trend with depth (Elderfield et al., 1982). If $\mathrm{Mg} / \mathrm{Ca}$ ratios reflect the history of oceanic composition, the patterns vs. age from the various sites should be similar.

If calcite were in equilibrium solely with the present-day interstitial water at each site, calcite $\mathrm{Mg} / \mathrm{Ca}$ ratios should reflect the pattern of $\mathrm{Mg} / \mathrm{Ca}$ ratios in interstitial water at these sites (Fig. 1B), with equilibrium values of $0.5-1.5 \mathrm{mmol} / \mathrm{mol}$ based on an effective partition coefficient for $\mathrm{Mg}$ in inorganic calcite of $0.5 \times 10^{-3}$ (Baker et al., 1982; Delaney, 1989). Time-averaging interstitial water compositions (using models based on Delaney, 1989) does not change the relative order of calcite $\mathrm{Mg} / \mathrm{Ca}$ values expected for these sites, although the predicted equilibrium $\mathrm{Mg} / \mathrm{Ca}$ ratios from the time-averaged results are up to a factor of 3 higher than those based on the present interstitial water composition. Instead of reflecting interstitial water $\mathrm{Mg} / \mathrm{Ca}$ ratios, calcite $\mathrm{Mg} / \mathrm{Ca}$ ratios appear to vary with site water depth, with the deeper Sites 803 and 804 having the lowest $\mathrm{Mg} / \mathrm{Ca}$ ratios, and the shallower Sites 806 and 807 having the highest ones. However, if $\mathrm{Mg} / \mathrm{Ca}$ ratios do reflect contamination from a noncalcite component not successfully removed by sample treatment, then the $\mathrm{Mg} / \mathrm{Ca}$ ratios are lower in the lower carbonate sites contrary to expectations. In a study of nonstructural diagenesis of core-top planktonic foraminifers, Lorens et al. (1977) found substantial decreases in $\mathrm{Mg} / \mathrm{Ca}$ ratios with increasing site water depth, with little change in $\mathrm{Sr} / \mathrm{Ca}$ ratios. Partial dissolution effects on the trace element composition of bulk calcite have not been studied, but the site-to-site differences in $\mathrm{Mg} / \mathrm{Ca}$ ratios indicate this may be an important factor.

Previous observations of calcite recrystallization in marine sediments have found higher $\mathrm{Mg} / \mathrm{Ca}$ ratios with lower $\mathrm{Sr} / \mathrm{Ca}$ ratios (Baker et al., 1982; Delaney, 1989), although this correlation may be affected by the sample treatment used (Apitz, 1991). The $\mathrm{Mg} / \mathrm{Ca}$ ratios are generally correlated to the $\mathrm{Sr} / \mathrm{Ca}$ ratios in the treated samples (Fig. 6), with a linear regression of $R^{2}=0.49$ for the data from all the sites, and $R^{2}=0.32-0.85$ for individual sites. The correlation of bulk leach $\mathrm{Mg} / \mathrm{Ca}$ ratios with treated $\mathrm{Sr} / \mathrm{Ca}$ ratios is much weaker, with $R^{2}=0.24$ for Site 804 samples and $R^{2}=$ only 0.04 for Site 806 samples, indicating no significant correlation. The controls on $\mathrm{Mg}$ incorporation in biogenic and inorganic calcite are poorly understood, and this incorporation is apparently sensitive to a number of environmental 


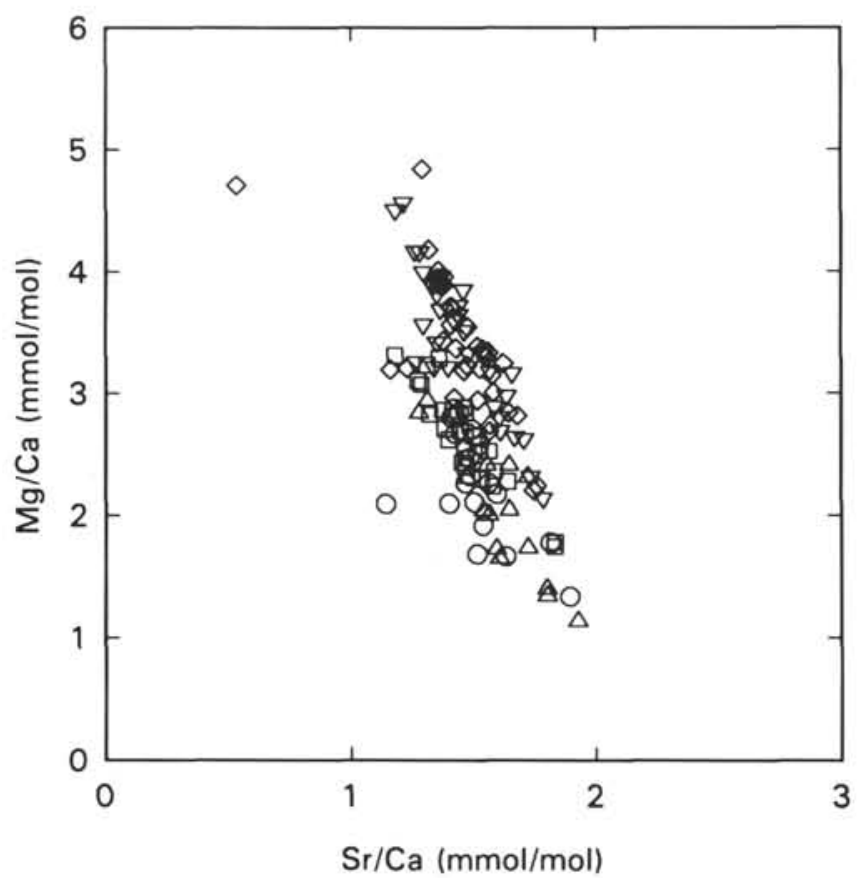

Figure 6. $\mathrm{Mg} / \mathrm{Ca}$ vs. $\mathrm{Sr} / \mathrm{Ca}$ ratios (treated samples) for all sites. Symbols for each site are as in Figure 4.

parameters (Morse and Bender, 1990; Apitz, 1991). The interpretation of these $\mathrm{Mg} / \mathrm{Ca}$ ratios remains uncertain.

\section{CONCLUSIONS}

The results of observations of minor element ratios in bulk sediment samples from Leg 130 sites demonstrate the importance of a sample treatment protocol including reductive and ion exchange steps (Apitz, 1991) for determining $\mathrm{Mg} / \mathrm{Ca}$ ratios, with minor effects on $\mathrm{Sr} / \mathrm{Ca}$ ratios. The $\mathrm{Mn} / \mathrm{Ca}$ and $\mathrm{Fe} / \mathrm{Ca}$ ratios measured using this protocol are not easily interpretable as reflecting calcite geochemistry records of paleocean chemistry or diagenetic overprinting. Celestite precipitation may limit interstitial water $\mathrm{Sr}$ concentrations, thus influencing the environment for calcite recrystallization. The $\mathrm{Sr} / \mathrm{Ca}$ ratios for the treated sediment samples vary with sample age in a similar fashion from site to site, with no distinctive site differences reflecting differing calcite recrystallization signatures. Interstitial water $\mathrm{Ca}$ and $\mathrm{Mg}$ gradients vary with basement characteristics. The $\mathrm{Mg} / \mathrm{Ca}$ ratios in the treated bulk sediment samples, presumably reflecting calcite geochemistry, weakly correlate with $\mathrm{Sr} / \mathrm{Ca}$ ratios and may have been affected by differing effects of partial dissolution correlated with site water depth differences. They do not appear to reflect oceanic chemical history or any straightforward influence of calcite recrystallization or contamination by other sediment phases.

\section{ACKNOWLEDGMENTS}

This work was supported by the U.S. Science Program associated with the Ocean Drilling Program sponsored by the National Science Foundation and the Joint Oceanographic Institutions, Inc. Any opinions, findings, and conclusions or recommendations expressed in this publication are those of the authors and do not necessarily reflect the views of NSF, JOI, Inc., or Texas A\&M University. We thank the shipboard scientific party and the ODP staff for the opportunity to collect and analyze these samples. We also thank R. Franks and the UCSC IMS Marine Analytical Facilities for their consistent and highquality support of this research and G. Filippelli for his comments.

\section{REFERENCES}

Apitz, S.E., 1991. The lithification of ridge flank basal carbonates: characterization and implications for $\mathrm{Sr} / \mathrm{Ca}$ and $\mathrm{Mg} / \mathrm{Ca}$ in marine chalks and limestones [Ph.D. dissert.]. Univ. of California, San Diego.

Baker, P.A., and Bloomer, S.H., 1986. The origin of celestite in deep-sea carbonate sediments. Geochim. Cosmochim. Acta, 52:335-339.

Baker, P.A., Gieskes, J.M., and Elderfield H., 1982. Diagenesis of carbonates in deep-sea sediments - evidence from $\mathrm{Sr} / \mathrm{Ca}$ ratios and interstitial dissolved $\mathrm{Sr}^{+2}$ data. J. Sediment. Petrol., 52:71-82.

Berger, W.H., Kroenke, L.W., Mayer, L.A., and Shipboard Scientific Party, 1991. Ontong Java Plateau, Leg 130: synopsis of major drilling results. In Kroenke, L.W., Berger, W.H., Janecek, T.R., et al., Proc. ODP, Init. Repts., 130: College Station, TX (Ocean Drilling Program), 497-537.

Boyle, E.A., 1981. Cadmium, zinc, copper, and barium in foraminifera tests. Earth Planet. Sci. Lett., 53:11-35.

, 1983. Manganese carbonate overgrowths on foraminifera tests. Geochim. Cosmochim. Acta, 47:1815-1819.

Delaney, M.L., 1989. Temporal changes in interstitial water chemistry and calcite recrystallization in marine sediments. Earth Planet. Sci. Lett., 95:23-37.

Delaney, M.L., and Shipboard Scientific Party, 1991. Inorganic geochemistry summary. In Kroenke, L.W., Berger, W.H., Janecek, T.R., et al., Proc. ODP, Init. Repts., 130: College Station, TX (Ocean Drilling Program), 549-551.

Elderfield, H., and Gieskes, J.M., 1982. Sr isotopes in interstitial waters of marine sediments from Deep Sea Drilling Project cores. Nature, 300: 493-497.

Elderfield, H., Gieskes, J.M., Oldfield, R.K., Hawkesworth, C.J., and Miller, R., $1982 .{ }^{87} \mathrm{Sr} /{ }^{86} \mathrm{Sr}$ and ${ }^{18} \mathrm{O} /{ }^{16} \mathrm{O}$ ratios, interstitial water chemistry and diagenesis in deep-sea carbonate sediments of the Ontong Java Plateau. Geochim. Cosmochim. Acta, 46:2259-2268.

Gieskes, J.M., Elderfield, H., and Palmer, M.R., 1986. Strontium and its isotopic composition in interstitial waters of marine carbonate sediments. Earth Planet. Sci. Lett., 77:229-235.

Gieskes, J.M., and Johnson, K., 1984. Interstitial water studies, Leg 81. In Roberts, D. G., Schnitker, D., et al., Init. Repts. DSDP, 81: Washington (U.S. Govt. Printing Office), 829-836.

Graham, D.W., Bender, M.L., Williams, D.F., and Keigwin, L.D., Jr., 1982. Strontium-calcium ratios in Cenozoic planktonic foraminifera. Geochim. Cosmochim. Acta, 46:1281-1292.

Lorens, R.B., Williams, D.F., and Bender, M.L., 1977. The early nonstructural chemical diagenesis of foraminiferal calcite. J. Sediment. Petrol., 47: 1602-1609.

McDuff, R.E., 1981. Major cation gradients in DSDP interstitial waters: the role of diffusive exchange between seawater and upper oceanic crust. Geochim. Cosmochim. Acta, 45:1705-1713.

Morse, J.W., and Bender, M.L., 1990. Partition coefficients in calcite: examination of factors influencing the validity of experimental results and their application to natural systems. Chem. Geol., 82:265-277.

Renard, M., 1986. Pelagic carbonate chemostratigraphy $\left(\mathrm{Sr}, \mathrm{Mg},{ }^{18} \mathrm{O},{ }^{13} \mathrm{C}\right)$. Mar. Micropaleontol., 10:117-164.

Richter, F.M., and DePaolo, D.J., 1987. Numerical models for diagenesis and the Neogene $\mathrm{Sr}$ isotopic evolution of seawater from DSDP Site 590B. Earth Planet. Sci. Lett., 83:27-38.

1988. Diagenesis and Sr isotopic evolution of seawater using data from DSDP 590B and 575. Earth Planet. Sci. Lett., 90:382-394.

Stout, P. M., 1985. Interstitial water chemistry and diagenesis of biogenic sediments from the eastern equatorial Pacific, Deep Sea Drilling Project Leg 85. In Mayer, L., Theyer, F., Thomas, E., et al., Init. Repts. DSDP, 85: Washington (U.S. Govt. Printing Office), 805-820.

Date of initial receipt: 30 August 1991

Date of acceptance: 12 February 1992

Ms 130B-038 
APPENDIX A

Bulk Calcite Minor Element Composition for Site 803 Samples

\begin{tabular}{|c|c|c|c|c|}
\hline $\begin{array}{l}\text { Core, section, } \\
\text { interval }(\mathrm{cm})\end{array}$ & $\begin{array}{l}\text { Depth } \\
\text { (mbsf) }\end{array}$ & $\begin{array}{l}\text { Age } \\
(\mathrm{Ma})\end{array}$ & $\mathrm{Sr} / \mathrm{Ca}$ & $\mathrm{Mg} / \mathrm{Ca}$ \\
\hline \multicolumn{5}{|l|}{ 130-803D- } \\
\hline $2 \mathrm{H}-4,145-150$ & 8.45 & 0.8 & 1.90 & 1.34 \\
\hline $3 \mathrm{H}-4,145-150$ & 17.95 & 1.8 & 1.56 & 2.26 \\
\hline $4 \mathrm{H}-4,145-150$ & 27.45 & 2.5 & 1.49 & 2.71 \\
\hline $5 \mathrm{H}-4,145-150$ & 36.95 & 3.2 & 1.47 & 2.26 \\
\hline $6 \mathrm{H}-4,145-150$ & 46.45 & 3.8 & 1.44 & 2.84 \\
\hline $7 \mathrm{H}-4,145-150$ & 52.05 & 4.1 & 1.49 & 2.32 \\
\hline $10 \mathrm{H}-4,145-150$ & 80.55 & 5.4 & 1.47 & 2.54 \\
\hline $13 \mathrm{H}-4,145-150$ & 109.05 & 6.4 & 1.42 & 2.82 \\
\hline $16 \mathrm{H}-4,145-150$ & 137.55 & 7.4 & 1.41 & 2.80 \\
\hline $19 \mathrm{H}-4,145-150$ & 166.05 & 8.4 & 1.60 & 2.17 \\
\hline $22 \mathrm{H}-4,145-150$ & 194.55 & 12.5 & 1.51 & 2.65 \\
\hline $25 \mathrm{X}-3,145-150$ & 221.55 & 13.7 & 1.49 & 2.47 \\
\hline $28 \mathrm{X}-3,145-150$ & 250.35 & 15.9 & 1.52 & 2.51 \\
\hline $31 X-2,145-150$ & 277.65 & 22.7 & 1.42 & 2.87 \\
\hline $34 X-4,140-150$ & 309.20 & 24.3 & 1.43 & 2.67 \\
\hline $37 X-5,140-150$ & 339.70 & 25.9 & 1.52 & 2.57 \\
\hline $40 \times-2,140-150$ & 364.20 & 27.3 & 1.82 & 1.78 \\
\hline $43 X-3,140-150$ & 394.80 & 29.1 & 1.50 & 2.10 \\
\hline $46 \times-4,140-150$ & 425.20 & 30.8 & 1.63 & 1.67 \\
\hline $49 X-3,140-150$ & 452.20 & 32.3 & 1.14 & 2.09 \\
\hline $52 X-1,140-150$ & 478.30 & 33.8 & 1.54 & 1.92 \\
\hline $55 X-4,140-150$ & 508.90 & 35.6 & 1.40 & 2.10 \\
\hline $59 \mathrm{X}-1,140-150$ & 545.70 & 37.7 & 1.52 & 1.68 \\
\hline $68 \mathrm{R}-1,138-150$ & 623.18 & 45.2 & $(2.79$ & 27.31) \\
\hline
\end{tabular}

Note: Elemental ratios in $\mathrm{mmol} / \mathrm{mol}$.

${ }^{a}$ Sample has a low carbonate content $(<1 \%)$; results are not

representative of calcite and are excluded from figures.

\section{APPENDIX B}

Bulk Calcite Minor Element Composition for Site 804 Samples

\begin{tabular}{|c|c|c|c|c|c|c|c|c|c|c|}
\hline \multirow{2}{*}{$\begin{array}{l}\text { Core, section, } \\
\text { interval }(\mathrm{cm})\end{array}$} & \multirow{2}{*}{$\begin{array}{l}\text { Depth } \\
\text { (mbsf) }\end{array}$} & \multirow{2}{*}{$\begin{array}{l}\text { Age } \\
(\mathrm{Ma})\end{array}$} & \multicolumn{4}{|c|}{ Treated } & \multicolumn{4}{|c|}{ Bulk leach } \\
\hline & & & $\mathrm{Sr} / \mathrm{Ca}$ & $\mathrm{Mg} / \mathrm{Ca}$ & $\mathrm{Mn} / \mathrm{Ca}$ & $\mathrm{Fe} / \mathrm{Ca}$ & $\mathrm{Sr} / \mathrm{Ca}$ & $\mathrm{Mg} / \mathrm{Ca}$ & $\mathrm{Mn} / \mathrm{Ca}$ & $\mathrm{Fe} / \mathrm{Ca}$ \\
\hline \multicolumn{11}{|l|}{$130-804 \mathrm{~B}-$} \\
\hline $1 \mathrm{H}-2,145-150$ & 2.95 & 0.3 & 1.80 & 1.36 & 0.330 & 0.144 & 1.73 & 4.72 & 0.772 & 0.074 \\
\hline $2 \mathrm{H}-4,145-150$ & 10.65 & 1.0 & 1.54 & 2.06 & 0.978 & 0.069 & 1.65 & 4.35 & 1.619 & 0.051 \\
\hline $3 \mathrm{H}-4,145-150$ & 20.15 & 2.0 & 1.56 & 2.02 & 0.750 & 0.089 & 1.65 & 4.47 & 1.559 & 0.055 \\
\hline $4 \mathrm{H}-4,145-150$ & 29.65 & 2.8 & 1.60 & 1.75 & 1.057 & 0.179 & 1.83 & 4.16 & 0.966 & 0.123 \\
\hline $5 \mathrm{H}-4,145-150$ & 39.15 & 3.6 & 1.72 & 2.33 & 0.945 & 0.132 & 1.60 & 4.89 & 0.868 & 0.185 \\
\hline $6 \mathrm{H}-4,145-150$ & 48.65 & 5.1 & 1.56 & 2.43 & 0.446 & 0.056 & 1.76 & 4.12 & 0.589 & 0.079 \\
\hline $9 \mathrm{H}-4,145-150$ & 77.15 & 7.3 & 1.28 & 2.86 & 0.327 & 0.046 & 1.48 & 4.78 & 0.340 & 0.047 \\
\hline $12 \mathrm{H}-4,145-150$ & 105.65 & 9.1 & 1.72 & 1.76 & 0.243 & 0.126 & 2.45 & 3.54 & 0.304 & 0.137 \\
\hline $15 \mathrm{H}-4,145-150$ & 134.15 & 9.9 & 1.80 & 1.42 & 0.507 & 0.104 & 2.05 & 3.31 & 1.799 & 0.395 \\
\hline \multicolumn{11}{|l|}{$130-804 \mathrm{C}$ - } \\
\hline $18 X-2,145-150$ & 161.25 & 11.5 & 1.93 & 1.15 & 0.363 & 0.100 & 1.77 & 3.09 & 0.434 & 0.110 \\
\hline $21 X-1,145-150$ & 188.85 & 14.0 & 1.31 & 2.96 & 0.920 & 0.016 & 1.43 & 4.47 & 1.261 & 0.025 \\
\hline $24 \mathrm{X}-1,140-150$ & 217.90 & 20.9 & 1.65 & 2.43 & 0.628 & 0.015 & 1.69 & 3.93 & 0.676 & 0.019 \\
\hline $27 \mathrm{X}-2,0-10$ & 246.90 & 22.9 & 1.65 & 2.06 & 0.578 & 0.018 & 1.84 & 4.10 & 0.716 & 0.021 \\
\hline $30 X-3,140-150$ & 278.80 & 29.4 & 1.47 & 2.32 & 0.382 & 0.017 & 1.50 & 3.76 & 0.438 & 0.025 \\
\hline $38 X-3,140-150$ & 307.49 & 33.2 & 1.61 & 1.67 & 0.298 & 0.014 & 1.79 & 3.46 & 0.389 & 0.026 \\
\hline
\end{tabular}

Note: Elemental ratios in $\mathrm{mmol} / \mathrm{mol}$. 
APPENDIX C

Bulk Calcite Minor Element Composition for Site 805 Samples

\begin{tabular}{|c|c|c|c|c|}
\hline $\begin{array}{l}\text { Core, section, } \\
\text { interval }(\mathrm{cm})\end{array}$ & $\begin{array}{l}\text { Depth } \\
\text { (mbsf) }\end{array}$ & $\begin{array}{l}\text { Age } \\
\text { (Ma) }\end{array}$ & $\mathrm{Sr} / \mathrm{Ca}$ & $\mathrm{Mg} / \mathrm{Ca}$ \\
\hline \multicolumn{5}{|l|}{$130-805 \mathrm{C}$ - } \\
\hline $1 \mathrm{H}-4,145-150$ & 5.95 & 0.4 & 1.84 & 1.78 \\
\hline $2 \mathrm{H}-4,145-150$ & 13.75 & 0.9 & 1.83 & 1.75 \\
\hline $3 \mathrm{H}-4,145-150$ & 23.25 & 1.5 & 1.58 & 2.23 \\
\hline $4 \mathrm{H}-4,145-150$ & 32.75 & 2.1 & 1.56 & 2.52 \\
\hline $5 \mathrm{H}-4,145-150$ & 42.25 & 2.4 & 1.47 & 2.84 \\
\hline $6 \mathrm{H}-4,145-150$ & 51.75 & 2.7 & 1.64 & 2.27 \\
\hline $9 \mathrm{H}-4,145-150$ & 80.25 & 3.6 & 1.50 & 2.65 \\
\hline $12 \mathrm{H}-4,145-150$ & 108.75 & 4.5 & 1.46 & 2.88 \\
\hline $15 \mathrm{H}-4,145-150$ & 137.20 & 5.3 & 1.36 & 3.29 \\
\hline $18 \mathrm{H}-4,140-150$ & 165.70 & 6.0 & 1.47 & 2.68 \\
\hline \multicolumn{5}{|l|}{$130-805 \mathrm{~B}-$} \\
\hline $20 \mathrm{H}-5,145-150$ & 183.65 & 6.5 & 1.38 & 2.71 \\
\hline $23 \mathrm{H}-4,145-150$ & 212.15 & 7.3 & 1.27 & 3.10 \\
\hline $26 \mathrm{H}-4,145-150$ & 240.65 & 8.0 & 1.18 & 3.31 \\
\hline $29 \mathrm{X}-4,145-150$ & 269.15 & 8.8 & 1.46 & 2.43 \\
\hline $32 X-2,140-150$ & 295.10 & 11.0 & 1.32 & 2.83 \\
\hline $35 X-3,140-150$ & 324.90 & 13.6 & 1.47 & 2.40 \\
\hline $38 X-3,140-150$ & 353.80 & 15.8 & 1.29 & 3.07 \\
\hline $41 X-3,140-150$ & 382.70 & 18.0 & 1.31 & 3.23 \\
\hline $44 X-5,140-150$ & 414.70 & 20.2 & 1.38 & 2.86 \\
\hline $48 X-3,140-150$ & 449.90 & 22.0 & 1.45 & 2.69 \\
\hline $50 X-3,140-150$ & 469.20 & 22.4 & 1.53 & 2.30 \\
\hline \multicolumn{5}{|l|}{$130-805 C-$} \\
\hline $53 \mathrm{X}-3,140-150$ & 499.30 & 24.2 & 1.40 & 2.62 \\
\hline $57 X-2,0-10$ & 535.00 & 26.0 & 1.59 & 2.36 \\
\hline $61 X-4,140-150$ & 578.20 & 28.3 & 1.47 & 2.47 \\
\hline
\end{tabular}

Note: Elemental ratios in $\mathrm{mmol} / \mathrm{mol}$. 
APPENDIX D

Bulk Calcite Minor Element Composition for Site 806 Samples

\begin{tabular}{|c|c|c|c|c|c|c|c|c|c|c|}
\hline \multirow{2}{*}{$\begin{array}{l}\text { Core, section, } \\
\text { interval }(\mathrm{cm})\end{array}$} & \multirow{2}{*}{$\begin{array}{l}\text { Depth } \\
\text { (mbsf) }\end{array}$} & \multirow{2}{*}{$\begin{array}{l}\text { Age } \\
(\mathrm{Ma})\end{array}$} & \multicolumn{4}{|c|}{ Treated } & \multicolumn{4}{|c|}{ Bulk leach } \\
\hline & & & $\mathrm{Sr} / \mathrm{Ca}$ & $\mathrm{Mg} / \mathrm{Ca}$ & $\mathrm{Mn} / \mathrm{Ca}$ & $\mathrm{Fe} / \mathrm{Ca}$ & $\mathrm{Sr} / \mathrm{Ca}$ & $\mathrm{Mg} / \mathrm{Ca}$ & $\mathrm{Mn} / \mathrm{Ca}$ & $\mathrm{Fe} / \mathrm{Ca}$ \\
\hline \multicolumn{11}{|l|}{$130-806 \mathrm{~B}-$} \\
\hline $1 \mathrm{H}-3,145-150$ & 4.45 & 0.2 & 1.66 & 3.14 & 0.650 & 0.050 & 1.71 & 5.92 & 0.316 & 0.055 \\
\hline $2 \mathrm{H}-4,145-150$ & 12.45 & 0.6 & 1.79 & 2.12 & 0.632 & 0.047 & 1.87 & 4.91 & 0.645 & 0.050 \\
\hline $3 \mathrm{H}-4,145-150$ & 11.95 & 1.0 & 1.74 & 2.29 & 0.579 & 0.031 & 1.86 & 5.17 & 0.513 & 0.041 \\
\hline $4 \mathrm{H}-4,145-150$ & 31.45 & 1.5 & 1.61 & 2.78 & 0.497 & 0.054 & 1.70 & 5.25 & 0.523 & 0.062 \\
\hline $5 \mathrm{H}-4,145-150$ & 40.95 & 1.9 & 1.61 & 2.67 & 0.629 & 0.032 & 1.71 & 4.86 & 0.499 & 0.038 \\
\hline $6 \mathrm{H}-4,145-150$ & 50.45 & 2.2 & 1.71 & 2.60 & 0.436 & 0.039 & 1.79 & 5.14 & 0.407 & 0.034 \\
\hline $9 \mathrm{H}-4,145-150$ & 78.95 & 3.1 & 1.67 & 2.62 & 0.354 & 0.021 & 1.76 & 4.87 & 0.284 & 0.031 \\
\hline $12 \mathrm{H}-4,145-150$ & 107.45 & 3.8 & 1.46 & 3.49 & 0.438 & 0.041 & 1.60 & 5.54 & 0.376 & 0.028 \\
\hline $15 \mathrm{H}-4,145-150$ & 135.95 & 4.4 & 1.64 & 2.96 & 0.198 & 0.013 & 1.81 & 4.89 & 0.164 & 0.014 \\
\hline $18 \mathrm{H}-4,145-150$ & 164.45 & 5.1 & 1.57 & 3.16 & 0.229 & 0.039 & 1.72 & 5.20 & 0.192 & 0.094 \\
\hline $21 \mathrm{H}-4,145-150$ & 192.95 & 5.7 & 1.46 & 3.83 & 0.256 & 0.017 & 1.56 & 5.76 & 0.191 & 0.023 \\
\hline $24 \mathrm{H}-4,145-150$ & 221.45 & 6.3 & 1.44 & 3.70 & 0.158 & 0.013 & 1.51 & 4.91 & 0.136 & 0.014 \\
\hline $27 \mathrm{H}-4,145-150$ & 249.95 & 6.9 & 1.48 & 3.31 & 0.149 & 0.013 & 1.58 & 4.85 & 0.125 & 0.010 \\
\hline $30 \mathrm{H}-5,140-150$ & 279.95 & 7.5 & 1.35 & 3.80 & 0.185 & 0.016 & 1.47 & 5.17 & 0.137 & 0.013 \\
\hline $33 \mathrm{H}-4,145-150$ & 306.95 & 8.1 & 1.18 & 4.48 & 0.203 & 0.014 & 1.30 & 5.66 & 0.255 & 0.027 \\
\hline $36 X-4,145-150$ & 335.65 & 8.7 & 1.42 & 3.58 & 0.207 & 0.017 & 1.55 & 4.83 & 0.177 & 0.022 \\
\hline $39 X-4,145-150$ & 364.70 & 9.7 & 1.40 & 3.20 & 0.286 & 0.023 & 1.46 & 4.62 & 0.236 & 0.022 \\
\hline $42 X-3,140-150$ & 392.30 & 10.7 & 1.59 & 2.87 & 0.241 & 0.032 & 1.69 & 4.03 & 0.207 & 0.031 \\
\hline $45 X-3,140-150$ & 421.30 & 11.7 & 1.44 & 3.62 & 0.165 & 0.030 & 1.53 & 4.72 & 0.171 & 0.034 \\
\hline $48 X-3,140-150$ & 450.20 & 12.7 & 1.28 & 4.14 & 0.236 & 0.047 & 1.37 & 4.94 & 0.199 & 0.055 \\
\hline $52 X-3,140-150$ & 487.00 & 14.1 & 1.22 & 4.54 & 0.292 & 0.162 & 1.29 & 5.24 & 0.228 & 0.175 \\
\hline $54 X-5,140-150$ & 509.30 & 15.2 & 1.30 & 3.98 & 0.306 & 0.135 & 1.38 & 4.84 & 0.263 & 0.138 \\
\hline $57 X-2,140-150$ & 533.80 & 16.5 & 1.26 & 4.15 & 0.204 & 0.250 & 1.33 & 5.26 & 0.206 & 0.240 \\
\hline $60 \times-4,0-7$ & 564.40 & 18.0 & 1.37 & 3.94 & 0.287 & 0.263 & 1.45 & 4.69 & 0.225 & 0.242 \\
\hline $63 X-4,140-150$ & 594.90 & 19.6 & 1.33 & 3.87 & 0.237 & 0.246 & 1.39 & 4.66 & 0.200 & 0.227 \\
\hline $66 \times-4,140-150$ & 623,80 & 20.8 & 1.37 & 3.67 & 0.174 & 0.096 & 1.48 & 4.53 & 0.156 & 0.099 \\
\hline $69 X-3,140-150$ & 650.90 & 21.8 & 1.30 & 3.55 & 0.248 & 0.270 & 1.43 & 4.47 & 0.187 & 0.264 \\
\hline $72 X-3,140-150$ & 679.90 & 22.9 & 1.35 & 3.40 & 0.234 & 0.226 & 1.44 & 4.18 & 0.182 & 0.224 \\
\hline $78 X-2,0-10$ & 706.00 & 23.9 & 1.26 & 3.24 & 0.181 & 0.305 & 1.35 & 4.14 & 0.168 & 0.261 \\
\hline \multicolumn{11}{|l|}{$130-806 \mathrm{C}$. } \\
\hline $61 X-4,140-150$ & 765.10 & 25.3 & 1.34 & 3.20 & 0.264 & 0.287 & 1.40 & 3.81 & 0.199 & 0.264 \\
\hline
\end{tabular}

Note: Elemental ratios in $\mathrm{mmol} / \mathrm{mol}$. 
APPENDIX E

Bulk Calcite Minor Element Composition for Site 807 Samples

\begin{tabular}{|c|c|c|c|c|}
\hline $\begin{array}{l}\text { Core, section, } \\
\text { interval }(\mathrm{cm})\end{array}$ & $\begin{array}{l}\text { Depth } \\
\text { (mbsf) }\end{array}$ & $\begin{array}{l}\text { Age } \\
\text { (Ma) }\end{array}$ & $\mathrm{Sr} / \mathrm{Ca}$ & $\mathrm{Mg} / \mathrm{Ca}$ \\
\hline \multicolumn{5}{|l|}{$130-807 \mathrm{~A}-$} \\
\hline $1 \mathrm{H}-3,145-150$ & 4.45 & 0.3 & 1.75 & 2.20 \\
\hline $2 \mathrm{H}-4,145-150$ & 13.35 & 0.9 & 1.76 & 2.24 \\
\hline $3 \mathrm{H}-4,145-150$ & 22.85 & 1.5 & 1.53 & 3.20 \\
\hline $4 \mathrm{H}-4,145-150$ & 32.35 & 2.1 & 1.57 & 2.74 \\
\hline $5 \mathrm{H}-4,145-150$ & 41.85 & 2.4 & 1.57 & 2.69 \\
\hline $6 \mathrm{H}-4,145-150$ & 51.35 & 2.7 & 1.47 & 3.23 \\
\hline $9 \mathrm{H}-4,145-150$ & 79.85 & 3.7 & 1.55 & 3.29 \\
\hline $12 \mathrm{H}-4,145-150$ & 108.35 & 4.6 & 1.58 & 3.15 \\
\hline $15 \mathrm{H}-5,145-150$ & 137.10 & 5.4 & 1.41 & 3.71 \\
\hline $18 \mathrm{H}-4,145-150$ & 165.35 & 6.1 & 1.37 & 3.89 \\
\hline $21 \mathrm{H}-4,145-150$ & 193.85 & 6.7 & 1.36 & 3.89 \\
\hline $24 \mathrm{H}-4,145-150$ & 222.35 & 7.3 & 1.34 & 3.90 \\
\hline $27 \mathrm{H}-4,145-150$ & 250.85 & 7.9 & 1.35 & 3.95 \\
\hline $30 \mathrm{H}-4,140-150$ & 279.70 & 8.5 & 1.58 & 3.01 \\
\hline $33 X-3,140-150$ & 306.70 & 10.2 & 1.46 & 3.19 \\
\hline $36 X-3,140-150$ & 335.30 & 12.6 & 1.41 & 3.71 \\
\hline $39 X-2,140-150$ & 362.80 & 14.4 & 1.56 & 3.33 \\
\hline $42 X-4,140-150$ & 395.10 & 16.0 & 1.32 & 4.18 \\
\hline $48 X-5,140-150$ & 425.70 & 17.6 & 1.29 & 4.84 \\
\hline $48 X-3,140-150$ & 451.50 & 18.9 & 1.38 & 3.96 \\
\hline $51 X-3,140-150$ & 480.50 & 20.3 & 1.36 & 4.00 \\
\hline $54 X-4,0-10$ & 509.60 & 21.8 & 1.38 & 3.89 \\
\hline $57 X-4,140-150$ & 539.60 & 22.8 & 1.54 & 3.33 \\
\hline $60 X-4,140-150$ & 568.50 & 23.8 & 1.48 & 3.54 \\
\hline $63 X-4,0-10$ & 596.10 & 24.7 & 1.54 & 3.36 \\
\hline $66 X-2,140-150$ & 623.50 & 25.6 & 1.62 & 3.25 \\
\hline $70 X-4,140-150$ & 665.10 & 27.0 & 1.65 & 2.84 \\
\hline $72 X-2,140-150$ & 681.10 & 27.5 & 1.68 & 2.82 \\
\hline $75 X-4,140-150$ & 713.10 & 30.5 & 1.52 & 3.39 \\
\hline $78 X-2,0-10$ & 737.70 & 31.2 & 1.41 & 3.56 \\
\hline $82 X-3,140-150$ & 778.90 & 32.3 & 1.38 & 3.43 \\
\hline \multicolumn{5}{|l|}{$130-807 \mathrm{C}$. } \\
\hline $4 \mathrm{R}-1,140-150$ & 810.40 & 33.1 & 1.43 & 3.37 \\
\hline $17 \mathrm{R}-1,140-150$ & 905.30 & 36.3 & 1.52 & 2.94 \\
\hline $23 \mathrm{R}-1,140-150$ & 940.10 & 37.8 & 1.42 & 2.96 \\
\hline $30 \mathrm{R}-1,71-76$ & 997.51 & 42.5 & 1.23 & 3.21 \\
\hline $40 \mathrm{R}-1,23-31$ & 1092.23 & 47.2 & 1.16 & 3.19 \\
\hline $46 \mathrm{R}-1,140-150$ & 1136.60 & 55.9 & 0.53 & 4.71 \\
\hline
\end{tabular}

Note: Elemental ratios in $\mathrm{mmol} / \mathrm{mol}$. 